\title{
A new approach to the method of drawing the Gaussen-Walter climate diagram
}

\author{
Waldemar Treder, Krzysztof Klamkowski, Katarzyna Wójcik \\ Research Institute of Horticulture, Konstytucji 3 Maja 1/3, 96-100 Skierniewice, Poland, e-mail: \\ krzysztof.klamkowski@inhort.pl
}

\begin{abstract}
In traditional climate diagrams a fixed coefficient $(\alpha)$ between temperature and precipitation has been adopted. It has been shown, however, that such an approach does not correctly describe the conditions of the climatic balance in Poland for the entire growing season. In this paper, a different solution to this problem is proposed the introduction of a variable coefficient for individual months. The analysis of patterns of climatic variables over the year supports the hypothesis that in order to estimate ETo only by means of mean air temperature $(E T o=\alpha \cdot T)$, the coefficient $\alpha$ should be variable for the individual months of the vegetative period. The values of the coefficient were empirically determined for use in calculating daily and monthly ETo. The newly proposed coefficients $\alpha$ were different from those determined with the standard climate diagram (published by Walter, Lieth 1967). The introduction of the variable value $\alpha$ into the computational model markedly improved the quality of the estimation of ETo. The mean bias errors determined for the estimation of ETo on the basis of temperature and the changing value of $\alpha$ were considerably lower than for the estimation of ETo with a fixed value of $\alpha$. This provides the possibility of a more accurate presentation of periods of both excess and shortage of precipitation.
\end{abstract}

Keywords: precipitation, evapotranspiration, temperature, water balance, drought

Submitted 11 July 2017, revised 2 October 2017, accepted 9 January 2018

\section{Introduction}

Local climatic conditions affect the possibilities for the development of agriculture by determining the species of crop plants and technologies that can be used for cultivation (Iglesias et al. 2012). In extreme cases, it is the abundance of water resources that determines development opportunities for regions and even whole countries. In terms of climate, the main weather factors that limit the growing of crops are the level of solar radiation, variations in temperature, and the amount of precipitation. In many parts of the world, the main factor limiting the possibilities for the cultivation of crops is the unavailability of water. One of the measures used to assess the water conditions of a specific area is its climatic water balance (Szwed et al. 2010; Radzka 2014). This balance determines the difference between precipitation and evapotranspiration. The values of the balance for each month of the growing season characterise the water conditions of the area, indicating potential needs for irrigation. The climatic criterion is based on the assumption that the consumption of water by plants is determined mainly by the weather pattern and the stage of plant development (Doorenbos, Pruitt 1977; Ley et al. 1994). Determinations of the climatic water balance are used not only in agriculture (Łabędzki, Bąk 2004), but also in climate and phytogeographical studies (Lauer 1960; de Azcárate 2013). In climatic and cartographic studies, pluvio-thermal conditions are often presented in the form of graphs or diagrams. One of the first diagrams depicting changes in precipitation and temperature was published by Hettner in 1891 (Lauer 1960). Gaussen (1954) and Walter (1955) found that with the right ratio between the ordinate axes, the diagram developed by Hettner could be used to estimate periods of excess or shortage of precipitation. The graphical comparison of mean temperatures and total precipitation for individual months was named the Gaussen-Walter diagram. The rule for the construction of such a graph is that the months should be plotted on the abscissa (X) and the mean air temperatures on the first (left) ordinate $\left(\mathrm{Y}_{1}\right)$. The values of total precipitation are plotted on a second (right) ordinate axis $\left(\mathrm{Y}_{2}\right)$ while maintaining a ratio of $1^{\circ} \mathrm{C}$ to $2 \mathrm{~mm}$ of precipitation. Periods of excess precipitation and drought are conveniently depicted with this type of diagram. Graphical representation of climatic water balance data can be an excellent tool for analysing and visually depicting water relations to facilitate the evaluation of an excess or shortage of precipitation in agriculture.

The Gaussen-Walter diagram directly represents data on the levels of temperature and precipitation only (such are the titles of the left and right ordinate axes, respectively); it can also be used to read off the amount of evapotranspiration and thus estimate the excess or shortage of precipitation. Such an approach might be useful under 
conditions of the limited availability of climatic data insufficient for the calculation of evapotranspiration when using standard models (e.g. the Penman-Monteith model). If, for a particular month, the temperature line is above the column representing the amount of precipitation, then the area below the line designates a negative water balance - a shortage of precipitation in relation to the estimated evapotranspiration (a period of drought). The amount of the shortage of precipitation for that month is the distance (downwards) between the temperature line and the top end of the column representing precipitation. The amount of the shortage in mm can be read off on the axis labelled 'precipitation'. Similarly, an excess of precipitation read off the diagram occurs when the temperature line intersects the column (or area) representing precipitation. The amount of excess rainfall is the distance (upwards) between the temperature line and the top end of the column depicting precipitation. The total evapotranspiration for each month (in $\mathrm{mm}$ ) is determined by the temperature line read off on the precipitation axis. Evapotranspiration is estimated using the simplest of the known models, which is based on temperature measurements only: ETo $=\alpha \cdot T$ ( $\alpha$ - empirically determined coefficient). For the original Gaussen-Walter diagram it was assumed that $\alpha=2$. Lauer (1960) showed, however, that this ratio is not suitable for all types of climate. In the climate diagram atlas published by Walter and Lieth (1967), to express wet and dry periods, the authors used a ratio of $1^{\circ} \mathrm{C}$ to $4,5 \mathrm{~mm}$ between the mean temperature of a particular month and the amount of precipitation (an example of such a diagram is presented in Fig. 7A). Pacholak (1989) also applied the same model of the climate diagram to depict periods of excess and shortage of precipitation in Poland. Łukasiewicz (2006), after analysing meteorological data for the station PoznańLawica $\left(52^{\circ} 25^{\prime} \mathrm{N}, 16^{\circ} 49^{\prime} \mathrm{E}\right)$, found that in the climate diagram for the conditions in Poland, a ratio of $1{ }^{\circ} \mathrm{C}$ to $4 \mathrm{~mm}$ of precipitation should be adopted between the axes representing the mean monthly air temperature and the total monthly precipitation. These examples show that so far during the plotting of climate diagrams, a fixed coefficient between temperature and precipitation has been adopted regardless of the season, with the literature giving different values for it (depending on the results of analyses of climatic conditions conducted by researchers). In this paper, we propose a different solution to this problem by introducing a variable coefficient for the individual months of the growing season.

The aim of this work is to develop a climate diagram that will describe precisely the climatic balance for the weather conditions in Poland.

\section{Materials and methods}

The meteorological measurements that were used to calibrate the model were performed between 2009 and 2010 in the localities of Białousy $\left(53^{\circ} 24^{\prime} \mathrm{N}, 23^{\circ} 13^{\prime} \mathrm{E}\right)$, Kondrajec Pański $\left(52^{\circ} 48^{\prime} \mathrm{N}, 20^{\circ} 13^{\prime} \mathrm{E}\right)$ and Skierniewice $\left(51^{\circ} 57^{\prime} \mathrm{N}, 20^{\circ} 09^{\prime} \mathrm{E}\right)$. The assessment of the quality of the model was conducted for the data obtained in the years 2013-2015 in the localities of Dąbrowice $\left(51^{\circ} 55^{\prime} \mathrm{N}\right.$, $\left.20^{\circ} 05^{\prime} \mathrm{E}\right)$ and Słoje $\left(53^{\circ} 19^{\prime} \mathrm{N}, 23^{\circ} 39^{\prime} \mathrm{E}\right)$. The soil at study sites was light, classified as having loamy, sandy texture.

The measurements were recorded by means of automatic meteorological stations (iMetos, Pessl Instruments, Austria) mounted at a height of 2 meters above the ground. The stations were equipped with a solar radiation sensor, which allowed the determination of reference evapotranspiration (ETo) using the Penman-Monteith (PMF 56) model (Doorenbos, Pruitt 1977; Allen et al. 1998).

$$
E T o=\frac{0,408 \Delta\left(R_{n}-G\right)+\gamma \frac{900}{T+273} u_{2}\left(e_{s}-e_{a}\right)}{\Delta+\gamma\left(1+0,34 u_{2}\right)}
$$

where: ETo - reference evapotranspiration $\left[\mathrm{mm} \cdot \mathrm{day}^{-1}\right]$; $R_{n}$ - net radiation $\left[\mathrm{MJ} \cdot \mathrm{m}^{-2} \cdot\right.$ day $\left.^{-1}\right] ; G-$ soil heat flux $\left[\mathrm{MJ} \cdot \mathrm{m}^{-2} \cdot\right.$ day $\left.^{-1}\right] ; \mathrm{T}-$ mean daily air temperature at a height of $2 \mathrm{~m}\left[{ }^{\circ} \mathrm{C}\right] ; u_{2}$ - wind speed at a height of $2 \mathrm{~m}\left[\mathrm{~m} \cdot \mathrm{s}^{-1}\right]$; $e_{s}-$ saturation vapour pressure $[\mathrm{kPa}] ; e_{a}-$ actual vapour pressure $[\mathrm{kPa}] ; e_{s}-e_{a}$ vapour pressure deficit $[\mathrm{kPa}]$; $\Delta$ - slope of the saturation vapour pressure-temperature curve $\left[\mathrm{kPa} \cdot{ }^{\circ} \mathrm{C}^{-1}\right] ; \gamma-$ psychrometric constant $\left[\mathrm{kPa} \cdot{ }^{\circ} \mathrm{C}^{-1}\right]$.

The assessment of the quality of the estimation of the ETo determined with the simplified model $(E T o=\alpha \cdot T)$ in relation to the PMF 56 model was performed using the mean bias error (MBE) (Sentelhas et al. 2010).

The $M B E\left(\mathrm{~mm} \cdot\right.$ day $\left.^{-1}\right)$ is defined as:

$$
M B E=\frac{\sum_{i=1}^{n}\left(P_{i}-O_{i}\right)}{n}
$$

where $P_{i}$ and $O_{i}$ are estimated and reference data, respectively, at the $i^{\text {th }}$ data point, and $n$ is the total number of data points.

Calculations were performed using the statistical package Statistica (StatSoft, USA).

\section{Results and discussion}

The climatic water balance contained in Gaussen-Walter diagrams is a relationship between mean monthly temperature and total precipitation, so the ETo is determined 


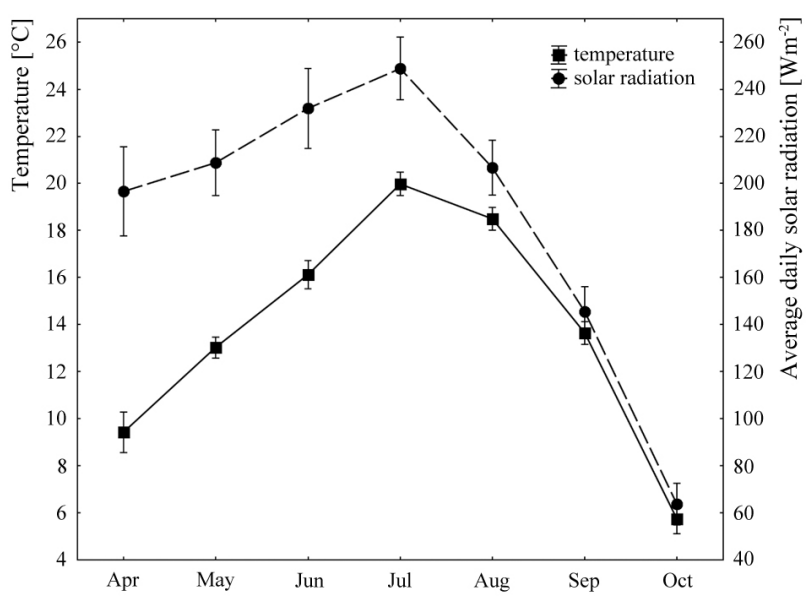

Fig. 1. Variations in air temperature and solar radiation during the growing season; mean values for all the stations and years of the study

here only on the basis of air temperature. The ratio balancing the mean monthly temperature with the amount of precipitation determines the amount of evapotranspiration per unit of temperature. The diagram in the climate atlas by Walter and Lieth (1967) has a 1:4,5 ratio between the temperature axis and the precipitation axis, which means that for a mean monthly temperature of $20^{\circ} \mathrm{C}$ the estimated evapotranspiration is $90 \mathrm{~mm}$ (zero climatic water balance). By dividing 4,5 by the number of days in the month, we obtain the value of the coefficient $\alpha$ by means of which we can estimate the amount of evapotranspiration for a specific day using the mean daily air temperature $(E T o=\alpha \cdot T)$. Because the ratio between the values of the two ordinate axes $Y_{1}$ and $Y_{2}$ in the diagram is fixed for all months of the year, for the months with 30 days $\alpha=0,15(4,5 / 30)$, and for those with 31 days $\alpha=0,145$. Further calculations assume the value of $\alpha=0,15$.

Figure 1 show the variations in temperature and solar radiation during the growing season (mean values for several stations and years of research). It is characteristic that in the spring there was a relatively high level of radiation at still low air temperatures. During the summer, the soil and the atmosphere accumulated large amounts of energy. A result of this was that in the autumn there were relatively high air temperatures despite the already low radiation. So, the ratio between temperature and radiation varied considerably during the growing season, which is the reason why the curves describing the process of evapotranspiration and the ratio between radiation and temperature have decidedly different shapes (Fig. 2).

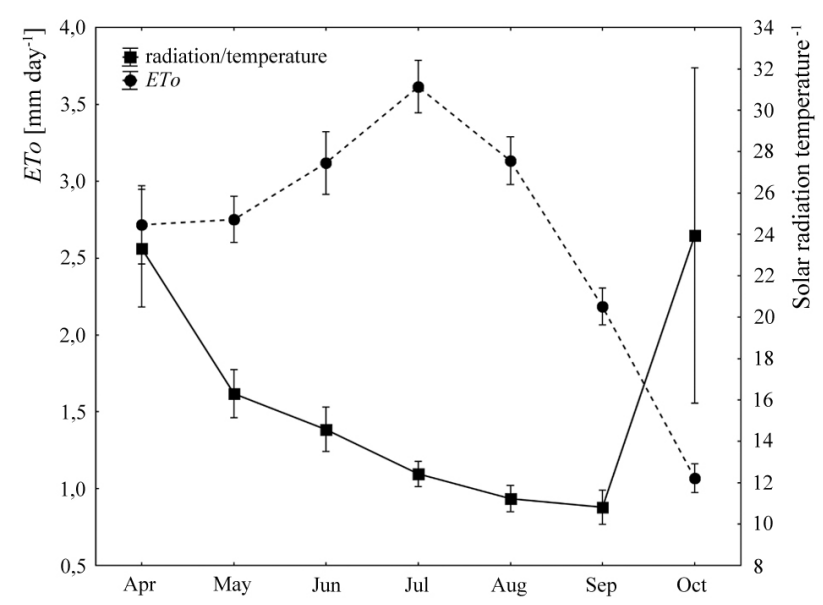

Fig. 2. Variations in ETo and the indicator of the level of radiation per unit temperature; mean values for all the stations and years of the study

The amount of evapotranspiration depends heavily on the level of solar radiation, and this relationship is taken into account by various computational models (Doorenbos, Pruitt 1977; Hargreaves, Samani 1985; Allen 1993; Ley et al. 1994; Allen et al. 1996; Xing et al. 2008). The pattern of variation in evapotranspiration during the growing season and the shape of the curve describing the level of radiation per unit of temperature indicate that in order to estimate ETo only by means of mean air temperature, the coefficient $\alpha$ should not be a fixed value but a variable $\left(\alpha_{\sim}\right)$ for the individual months of the growing season. To obtain the values of the $\alpha_{\sim}$ coefficient, linear regression analyses $(y=\alpha x+b)$ were performed individually for each month of the growing season (Apr-Oct) between mean daily temperature $(x)$ and the amount of ETo (y) (Fig. 3). The shape of the regression lines indicates a different relationship between temperature and evapotranspiration in each month of the growing season.

While determining the value of the intercept (b) at 0 , the values of daily coefficients $\left(\alpha_{\lrcorner d}\right)$, changing in individual months, were determined for use in calculating daily ETo. To obtain monthly coefficients $\left(\alpha_{\sim m}\right)$ for estimating the total evapotranspiration in a specific month, the value of $\alpha_{\sim d}$ was multiplied by the number of days in that month (Tab. 1). The empirically determined coefficients $\alpha_{\sim d}$ and $\alpha_{\sim m}$ reached the highest values in April, decreasing gradually in the subsequent months of the growing season. For all months, except October, they were higher than those determined with the climate diagram published by Walter and Lieth (1967).

Table 1. Values of $\alpha_{\sim}$ coefficients for each month of the growing season

\begin{tabular}{|l|c|c|c|c|c|c|c|}
\hline Coefficient & Apr & May & Jun & Jul & Aug & Sep & Oct \\
\hline$\alpha_{\sim d}$ for daily calculations & 0,28 & 0,21 & 0,194 & 0,182 & 0,170 & 0,160 & 0,146 \\
\hline$\alpha_{\sim m}$ for monthly calculations & 8,40 & 6,51 & 5,82 & 5,64 & 5,27 & 4,80 & 4,53 \\
\hline
\end{tabular}



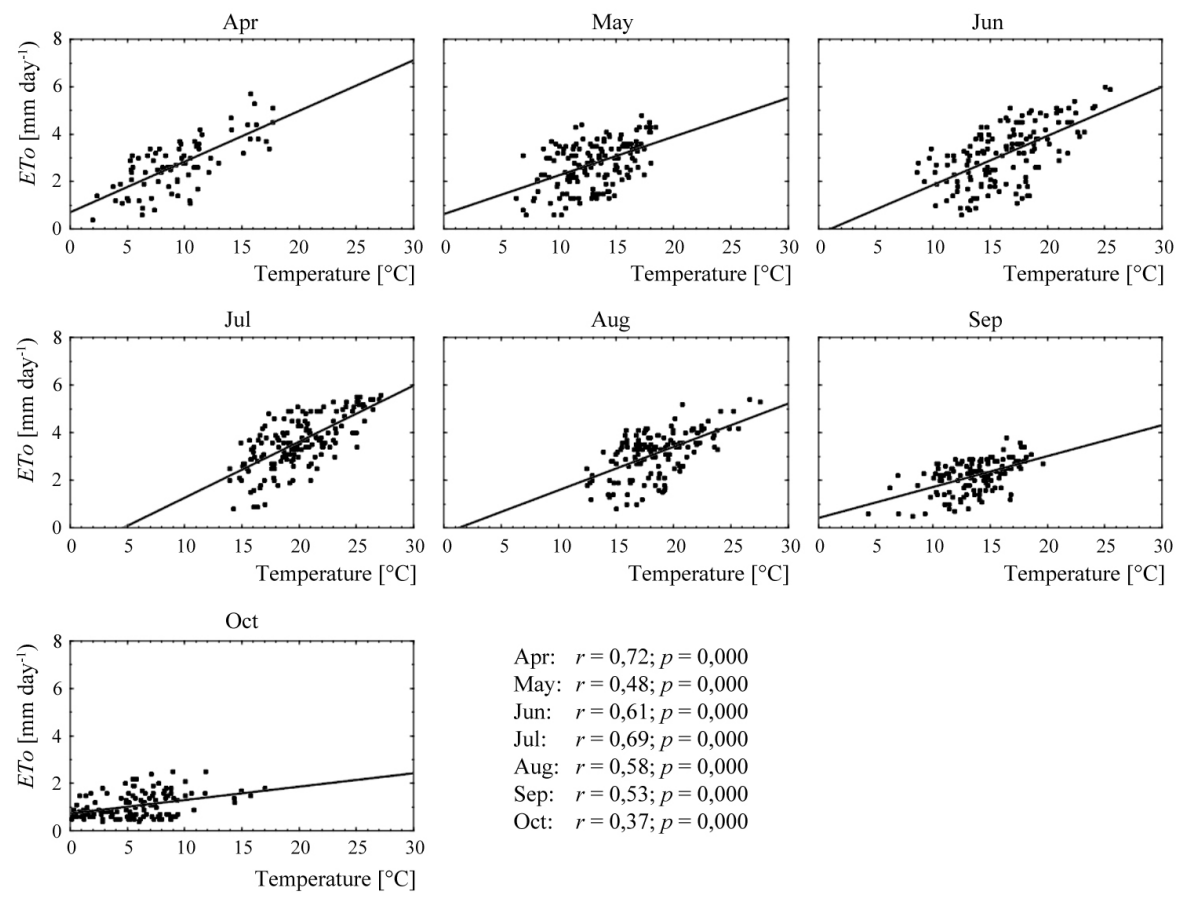

Fig. 3. The relationship between temperature and evapotranspiration in each month of the growing season; aggregate data for the stations and years of the study

Graphs 4 and 5 comprise assessments of the quality of the estimation of daily evapotranspiration only on the basis of measurements of mean air temperature and the coefficients $\alpha$ and $\alpha_{\sim d}$ in relation to the reference model PMF56. The introduction of the variable value $\alpha_{\sim}$ into the computational model markedly improved the quality of the estimation of ETo. For the two locations and for the period from April to August in all the years of the study, the $M B E$ errors determined for the estimation of ETo on the basis of temperature and the changing value of $\alpha$ were considerably smaller than for the estimation of ETo with a fixed value of $\alpha$ for all those months. The values of these errors reached a level similar to the values of the $M B E$ errors determined for the conditions in Canada when estimating ETo with simplified models, such as those of Priestley-Taylor, Hargreaves, or Thornthwaite (Sentelhas et al. 2010). In the autumn (Sep-Oct), there were no longer such marked differences between the values of $M B E$ errors for the two methods tested. This resulted from the comparable values of the $\alpha$ coefficients. The size of $M B E$ errors varied depending on the calculation method, location, year of study and conditions during the growing season. In the calculations for the spring (Apr-May) and autumn (SepOct) using a variable coefficient $\alpha$, the $M B E$ error was relatively low. However, during the summer it showed an underestimation of the ETo value in relation to the reference method. This was particularly evident in the hot and very dry growing season of 2015. It is most likely that this was due to the different weather conditions prevailing during the period in which the model was calibrated (the years 2009-2011 were characterised by moderate temperatures and a relatively high frequency of precipitation). The use of a fixed coefficient $\alpha$ for all the months, as is customary when constructing a climate diagram, resulted in a considerable underestimation of ETo during the spring and summer. The diagram presented by Walter and Lieth (1967) correctly describes the conditions of the climatic balance in Poland only in the autumn. In September and October, the $M B E$ errors were relatively low. The fixed ratio between the values of temperature and precipitation ( $Y_{1}$ and $Y_{2}$ axes), which is the principle of climate diagrams used thus far, without taking into account the changing relationship between temperature and radiation during the season, cannot properly describe the climatic balance during the entire growing period. We obtained a much smaller error in the balance using a variable value of $\alpha$ in the calculations.

The use of temperature only to determine evapotranspiration cannot be, in principle, a sufficiently precise method. The quality of the estimates depends here on the weather pattern during the growing season. This is confirmed by the variation in the amount of evapotranspiration determined for the data from individual years (Fig. 6). When air temperatures exceeded the mean values for the respective periods (2015), the proposed model gave ETo values lower than those calculated with the reference method. The quality of the estimates, however, was always better than that used in traditional climate diagrams.

For the climate diagram to accurately depict water balance, we propose breaking with the existing principle 


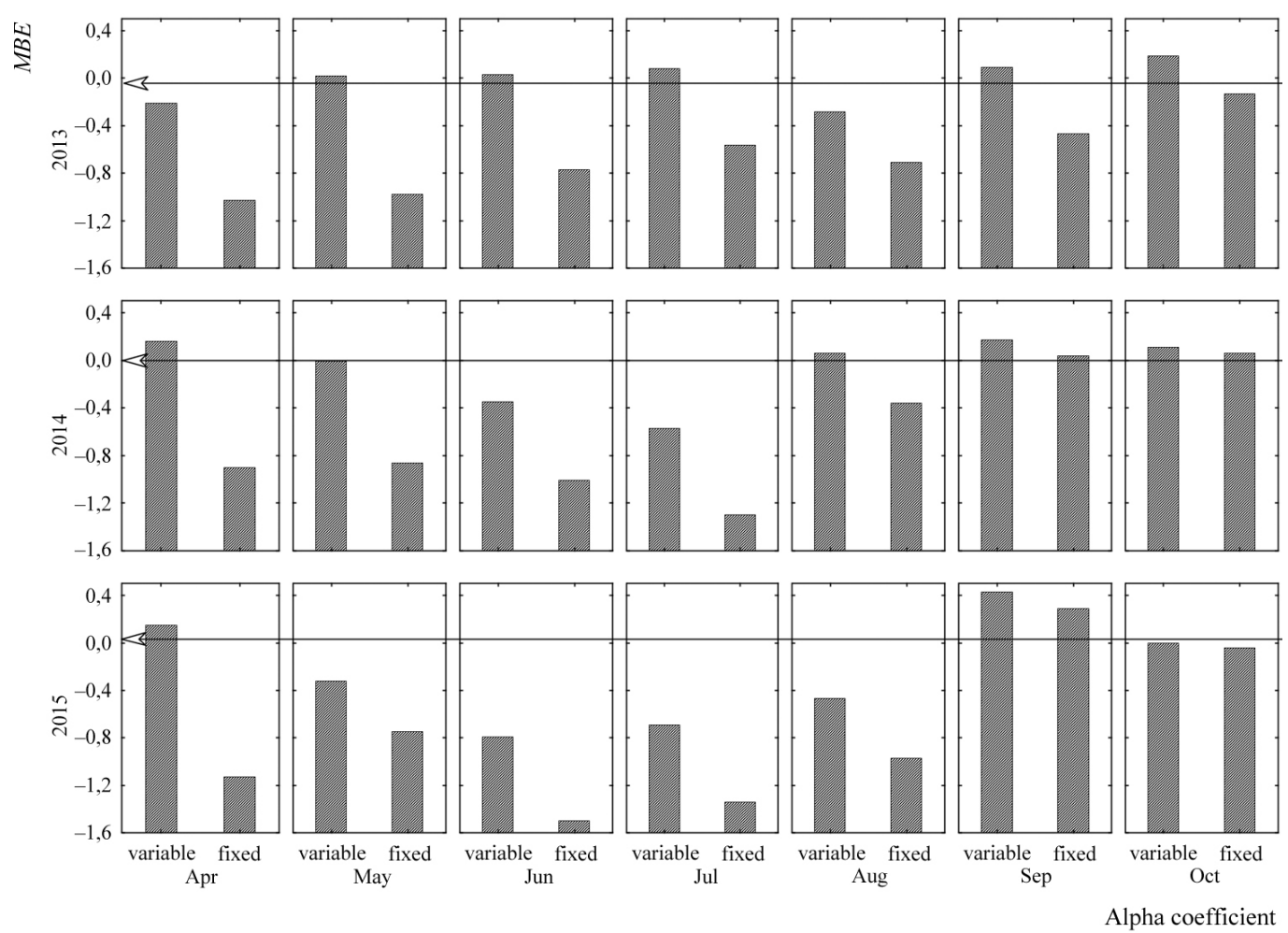

Fig. 4. Mean bias error $(M B E)$ for ETo estimated by temperature, and fixed or variable coefficient $\alpha$ in relation to the PMF56 reference model (Słoje, 2013-2015)
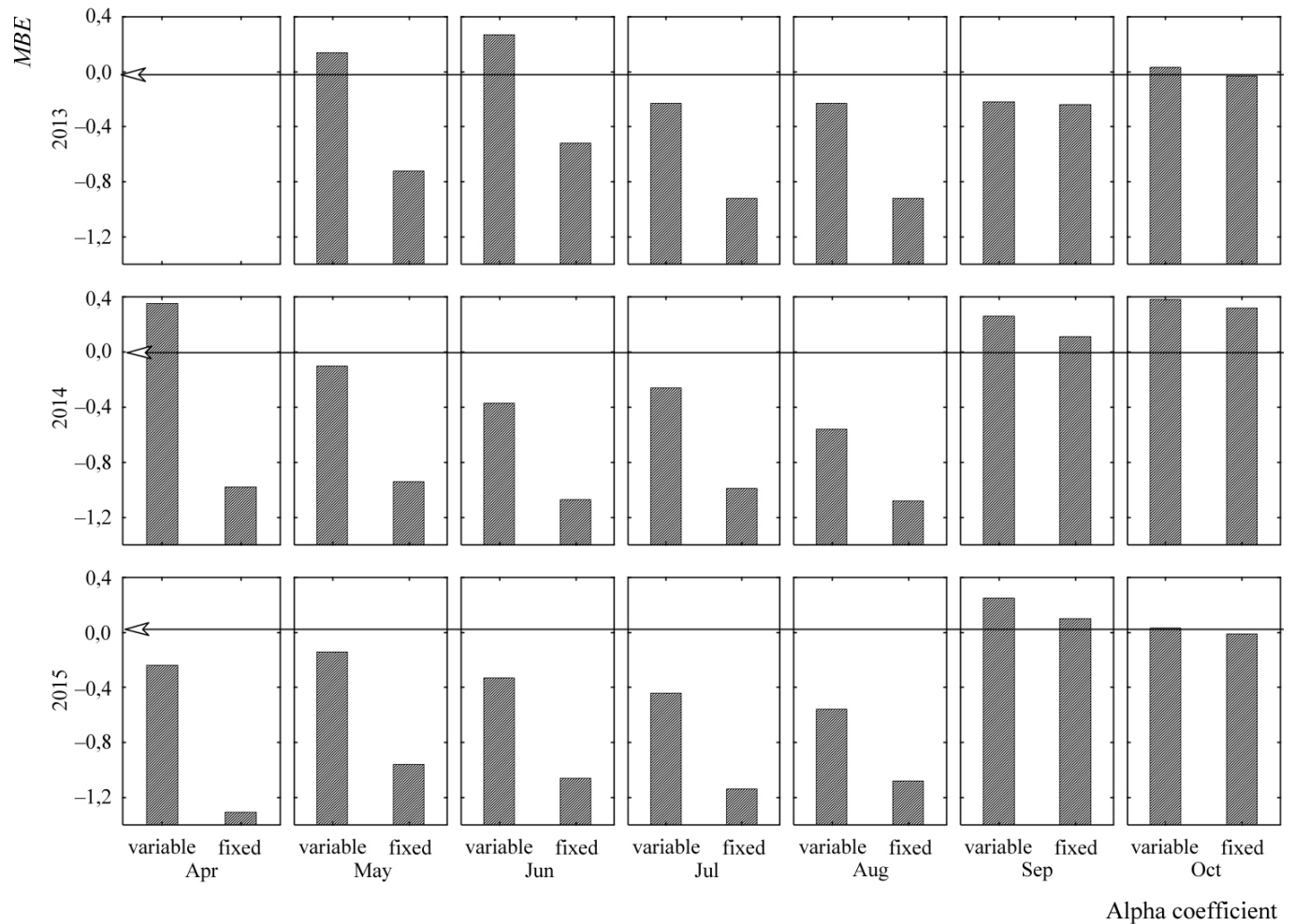

Fig. 5. Mean bias error (MBE) for ETo estimated by temperature, and fixed or variable coefficient $\alpha$ in relation to the PMF56 reference model (Dąbrowice, 2013-2015)

of setting a fixed ratio between the axes for temperature and precipitation. The proposed new version of the diagram gives the possibility not only of a more accurate presentation of the periods of excess and shortage of precipitation, but also offers the opportunity for the inde- pendent depiction of the variations in temperature and evapotranspiration, reference or actual, of a particular crop plant species. The principle of the preparation of the diagram is very simple. As in the conventional diagram, the labels for the months should be presented on 

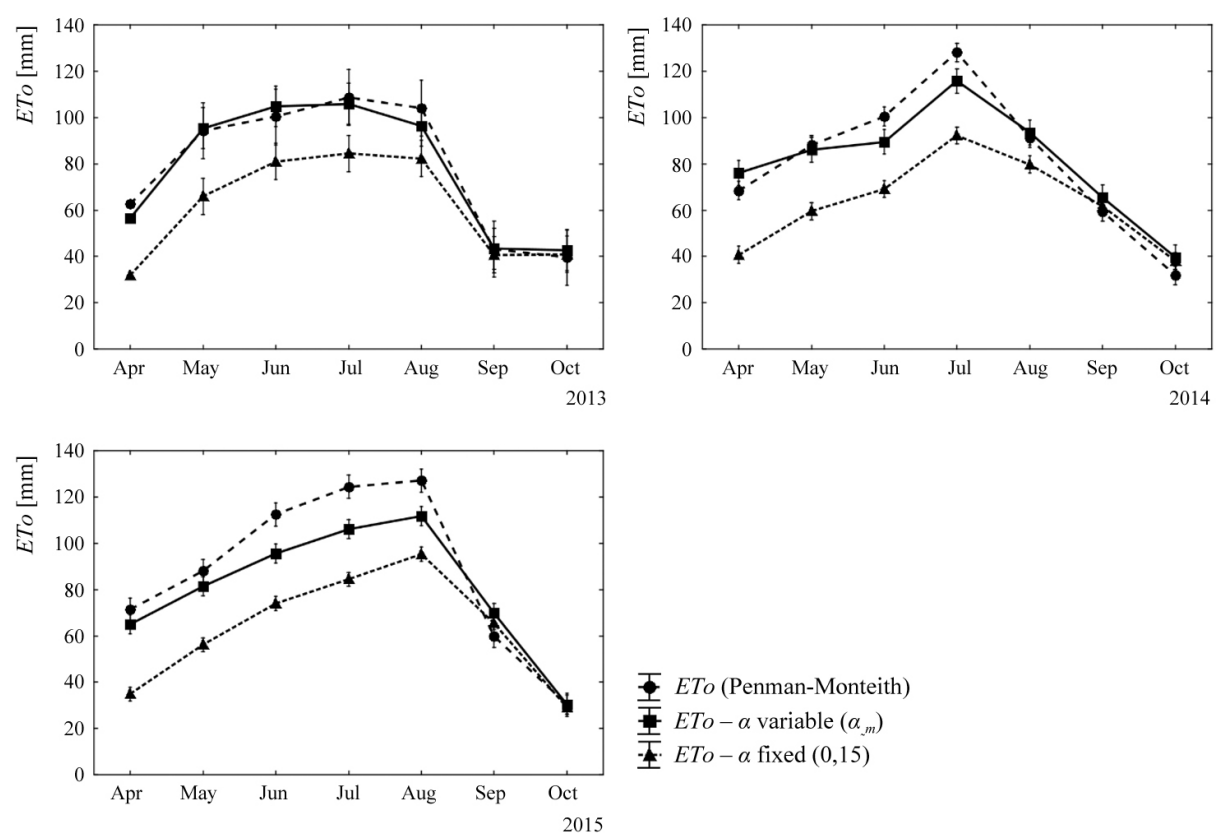

Fig. 6. Total monthly evapotranspiration determined with the evaluated methods; averaged data for both locations
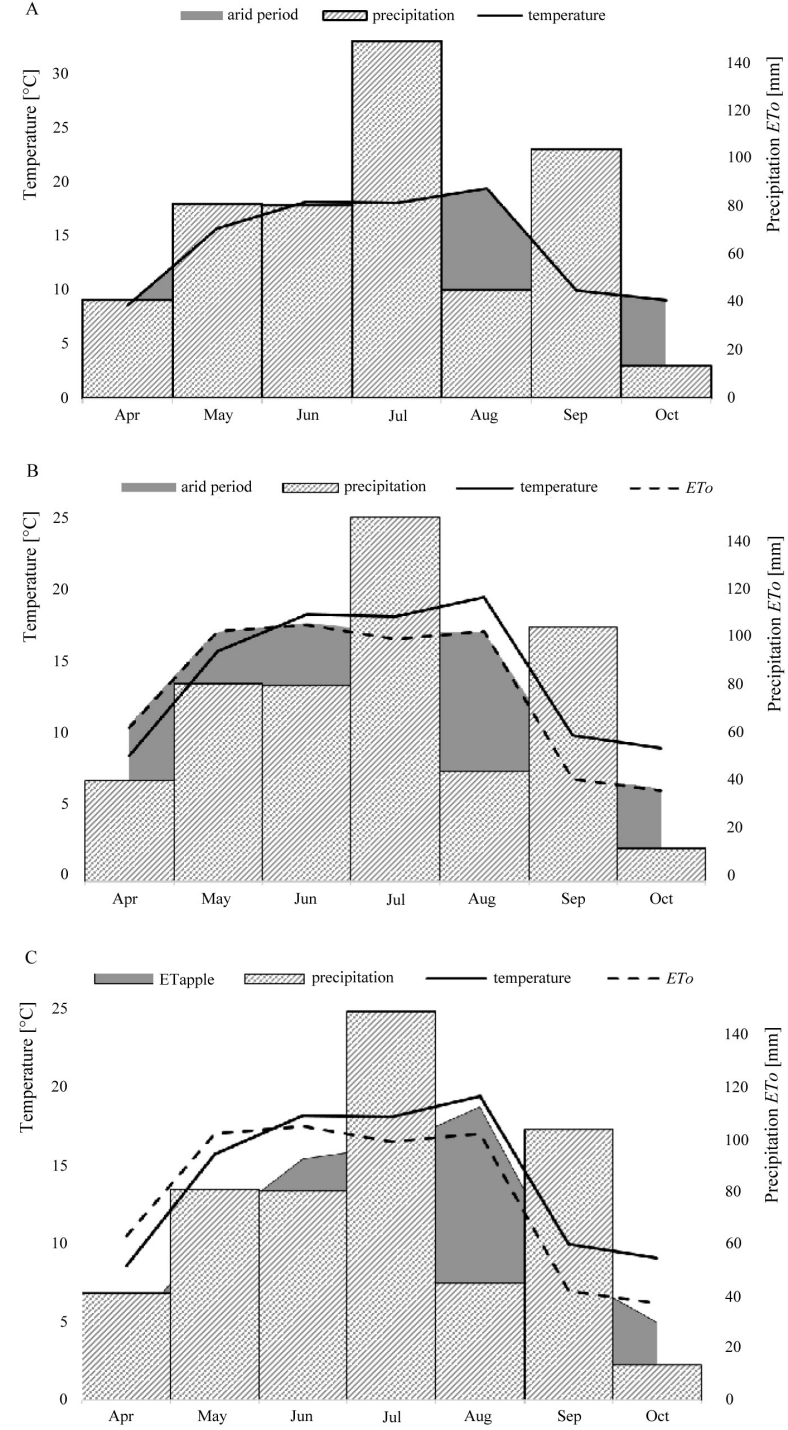

Fig. 7. Different versions of climate diagrams; A - traditional, $\mathrm{B}$ - new, $\mathrm{C}-$ new, including the value of the crop (apple) coefficient $k$ (Słoje, 2013) the abscissa $(\mathrm{X})$ and the values of mean air temperature on the first (left) ordinate $\left(\mathrm{Y}_{1}\right)$. Values of total precipitation and evapotranspiration determined according to the model ETo $=\alpha_{\sim} T$ are presented on a second (right) ordinate axis $\left(\mathrm{Y}_{2}\right)$. Because precipitation and evapotranspiration are shown on one axis $\left(\mathrm{Y}_{2}\right)$, areas of excess and shortage of precipitation are automatically determined in relation to the amount of evapotranspiration, and the ratio between $Y_{1}$ and $Y_{2}$ can be chosen arbitrarily depending on the needs of the researcher.

Graph 7 shows three climate diagrams (A, B, C) for the station Słoje and the 2013 growing season. The diagrams were prepared using the graphing functions in the Excel spreadsheet program.

- A - Gaussen-Walter diagram $\left(1^{\circ} \mathrm{C}: 4,5 \mathrm{~mm}\right.$ of precipitation);

- $\mathrm{B}-$ new version of the diagram $\left(E T o=\alpha_{\sim m} T\right)$;

$-\mathrm{C}-$ new version of the diagram $\left(E T_{\text {apple trees }}=k \cdot E T o\right)$.

According to the diagram proposed by Walter and Lieth (1967), in the spring there were slight shortages of precipitation only in April (Fig. 7A). In fact, a negative climatic water balance occurred in 3 consecutive months (Apr-Jun), which is shown by the new version of the climate diagram (Fig. 7B). Fig. 7C shows crop water balance for apple trees, which was determined by multiplying ETo by the corresponding values of the crop coefficient $k$ (Doorenbos, Pruitt 1977). The graph shows that in the case of apple trees a negative crop balance occurred in June, August and October. 


\section{Conclusions}

A. The analysis of the patterns of climatic variables (temperature, solar radiation) during the year indicated that in order to estimate ETo only by means of mean air temperature $(E T o=\alpha \cdot T)$, the coefficient $\alpha$ should not be a fixed value but a variable for the individual months of the growing season.

B. The values of $\alpha$ coefficient were empirically determined for use in calculating daily and monthly ETo in Polish climatic conditions.

C. It was proven that the introduction of the variable value $\alpha$ into the evapotranspiration computational model markedly improved the quality of the estimation of ETo. The quality of the estimates was better than that used in traditional climate diagrams, giving the possibility of a more accurate presentation of the periods of both excess and shortage of precipitation.

D. Given the strong evidence of an increase in global temperatures in recent decades, research in this area should be continued so that the results will have predictive value, containing elements of prognosis of future climate conditions.

\section{Acknowledgements}

This work was performed within the frame of the multiannual programme "Actions to improve the competitiveness and innovation in the horticultural sector with regard to quality and food safety and environmental protection", financed by the Polish Ministry of Agriculture and Rural Development

\section{Bibliography}

Allen R.G., 1993, New approaches to estimating crop evapotranspiration, Acta Horticulturae, 335, 287-294, DOI: 10.17660/ ActaHortic.1993.335.35

Allen R.G., Smith M., Pereira L.S., Pruitt W.O., 1996, Proposed revision to the FAO procedure for estimating crop water requirements, Acta Horticulturae, 449, 17-33, DOI: 10.17660/ActaHortic.1997.449.2

Allen R.G., Pereira L.S., Raes D., Smith M., 1998, Crop evapotranspiration. Guidelines for computing crop water requirements, FAO Irrigation and Drainage Paper, 56, Rome, Italy

de Azcárate J.G., Rodríguez M.A.M., Merino F.G., 2013, Bioclimatic belts of Sierra Madre Occidental (México): a preliminary approach, International Journal of Geobotanical Research, 3 (1), 19-35. DOI: 10.5616/ijgr130002

Doorenbos J., Pruitt W.O., 1977, Guidelines for predicting crop water requirements, FAO Irrigation and Drainage Paper, 24, Rome, Italy
Gaussen H., 1954, Théorie et classification des climats et microclimats. C.R. VIIIème Congres International de Botanique. Section 7, 125-130

Hargreaves G.H., Samani Z.A., 1985, Reference crop evapotranspiration from temperature, Applied Engineering in Agriculture, 1, 96-99, DOI: 10.13031/2013.26773

Iglesias A., Garrote L., Quiroga S., Moneo M., 2012, A regional comparison of the effects of climate change on agricultural crops in Europe, Climatic Change, 112 (1), 29-46, DOI: 10.1007/s10584-011-0338-8

Lauer W., 1960, Klimadiagramme: Gedanken und Bemerkungen über die Verwendung von Klimadiagrammen für die Typisierung und den Vergleich von Klimaten, Erdkunde, 14 (3), 232-242, DOI: 10.3112/erdkunde.1960.03.08

Ley T.W., Hill R.W., Jansen D.T., 1994, Errors in PenmanWright alfalfa reference evapotranspiration estimates: I. Model sensitivity analyses, Transactions of the ASAE, 37 (6), 1853-1861, DOI: 10.13031/2013.28276

Łabędzki L., Bąk B., 2004, Standardized climatic water balance as a drought index, (in Polish), Acta Agrophysica, 3 (1), 117-124

Łukasiewicz S., 2006, A suggested modification of the method of drawing the wet 'humid' period in the Gaussen-Walter climate diagram, (in Polish), Badania Fizjograficzne nad Polską Zachodnią. Seria A - Geografia Fizyczna, 57, 95-99

Pacholak E., 1986, Wpływ nawożenia i nawadniania na wzrost i plonowanie jabłoni odmiany James Grieve, (in Polish), Roczniki AR w Poznaniu, Rozprawy Naukowe, 160, 85 s.

Radzka E., 2014, Klimatyczny bilans wodny okresu wegetacyjnego (według wzoru Iwanowa) w środkowowschodniej Polsce, (in Polish), Woda - Środowisko - Obszary Wiejskie, 14 (1), 67-76

Sentelhas P.C., Gilespie T.J., Santos E., 2010, Evaluation of FAO Penman-Monteith and alternative models for estimating reference evapotranspiration with missing data in Southern Ontario, Canada, Agricultural Water Management, 97, 635644, DOI: 10.1016/j.agwat.2009.12.001

Szwed M., Karg G., Pińskwar I., Radziejewski M., Graczyk D., Kędziora A., Kundzewicz Z.W., 2010, Climate change and its effect on agriculture, water resources and human health sectors in Poland, Natural Hazards and Earth System Sciences, 10, 1725-1737, DOI: 10.5194/nhess-10-1725-2010

Walter H., 1955, Die Klimadiagramme als Mittel zur Beurteilung der Klimaverhältnisse für ökologische, vegetationskundliche und landwirtschaftliche Zwecke, Berichte der Deutschen Botanischen Gesellschaft, 68, 331-344

Walter H., Lieth H., 1967, Klimadiagramm - Weltatlas, Jena, VEB G. Fisher Verlag

Xing Z., Chow L., Meng F.R., Res H.W., Stevens L., Monteith L., 2008, Validating evapotranspiration equations using Bowen Ratio in New Brunswick, Maritime, Canada, Sensors, 8 (1), 412-428, DOI: $10.3390 / \mathrm{s} 8010412$ 
